\title{
Impact of a high rainfall event on the water level, current velocity, and total suspended solids in tidal flats environments of the estuarine Cruces River wetland, south-central Chile
}

\author{
Mario Manzano ${ }^{1,2}$, Eduardo Jaramillo ${ }^{2}$ \& Mario Pino ${ }^{3}$ \\ ${ }^{1}$ Programa Doctorado en Biología Marina, Facultad de Ciencias \\ Universidad Austral de Chile, Valdivia, Chile \\ ${ }^{2}$ Instituto de Ciencias de la Tierra, Facultad de Ciencias, Universidad Austral de Chile, Valdivia, Chile \\ ${ }^{3}$ Instituto de Ciencias de la Tierra \& TAQUACH, Facultad de Ciencias \\ Universidad Austral de Chile, Valdivia, Chile \\ Corresponding author: Mario Manzano (mario.a.manzano.c@gmail.com)
}

\begin{abstract}
The effects of a sudden rainfall $\left(40 \mathrm{~mm} \mathrm{~d}^{-1}\right)$ event on the surface waters covering muddy tidal flats were studied during April 2016 at the estuarine Cruces River wetland in south-central Chile $\left(\sim 40^{\circ} \mathrm{S}\right)$. The study area included flooded vestigial tree trunks, which is evidence of coseismic subsidence associated with the 1960 Valdivia earthquake as a source of environmental variability. The tidal flat with vestigial tree trunks registered the fastest and highest depth of inundation. In contrast, the tidal currents velocity and total suspended solids' concentrations were higher at the flat without trunks. Sudden rainfall events can significantly modify the characteristics of surface waters above sedimentary intertidal surfaces, where structures such as flooded trunks are present.
\end{abstract}

Keywords: estuarine wetlands; vestigial trunks; tide flooding; rainfall; southern Chile

One of the most striking pieces of evidence of coseismic continental subsidence in the rupture zone of the 1960 Valdivia earthquake was the deepening and widening of extensive fluvial zones and estuaries in south-central Chile (Plafker \& Savage 1970, Reinhardt et al. 2010). Consequently, this region's current landscape is characterized by numerous sandy and muddy tidal flats, with vestigial trunks, which represent the remnants of trees that occupied the former river banks (Feuker 2006). The flooded tree trunks rise above the water surface. They could, therefore, influence the tidal currents and the sedimentation of particles and concentrations of total suspended solids, as well as biogeochemical processes within the substrate (cf. Hackney \& Avery 2015, Pieterse et al. 2016).

While carrying field experiments during April 2016 at the estuary of the Cruces River wetland in Valdivia (Fig. 1a) and aimed to study the characteristics of flood and ebb waters on two near located tidal flats (Fig. 1b), an abnormal high rainfall event occurred. During the year, the event was generally characterized by low rainfall with a historical monthly average (April) of accumulated precipitation of $153 \mathrm{~mm}$ (1960-2016; UACh 2015). Nonetheless, $96 \mathrm{~mm}$ of accumulated rainfall, with a daily maximum of $40 \mathrm{~mm}$, occurred during April 19-24 during the first day and down to nearly $15 \mathrm{~mm}$ daily during 22-24 April (www. agromet.cl). This wet condition offered a unique opportunity to evaluate the effects of a high rainfall event on the depth of inundation and velocity of tidal currents and the concentrations of total suspended solids (TSS) in the water. Although the study was not replicated, the results are considered relevant for evaluating eventual sudden environmental perturbations and their effects on those sedimentary intertidal habitats. The results are also potentially useful for developing successful and adequate strategies for artificial optimization of recovery process related to massive inundation events on those coastal habitats (cf. Lindenmayer et al. 2010).

The two tidal flats are located in the southern sector of the Cruces River wetland (Figs. 1a-b), which is an

Corresponding editor: Marcel Ramos 


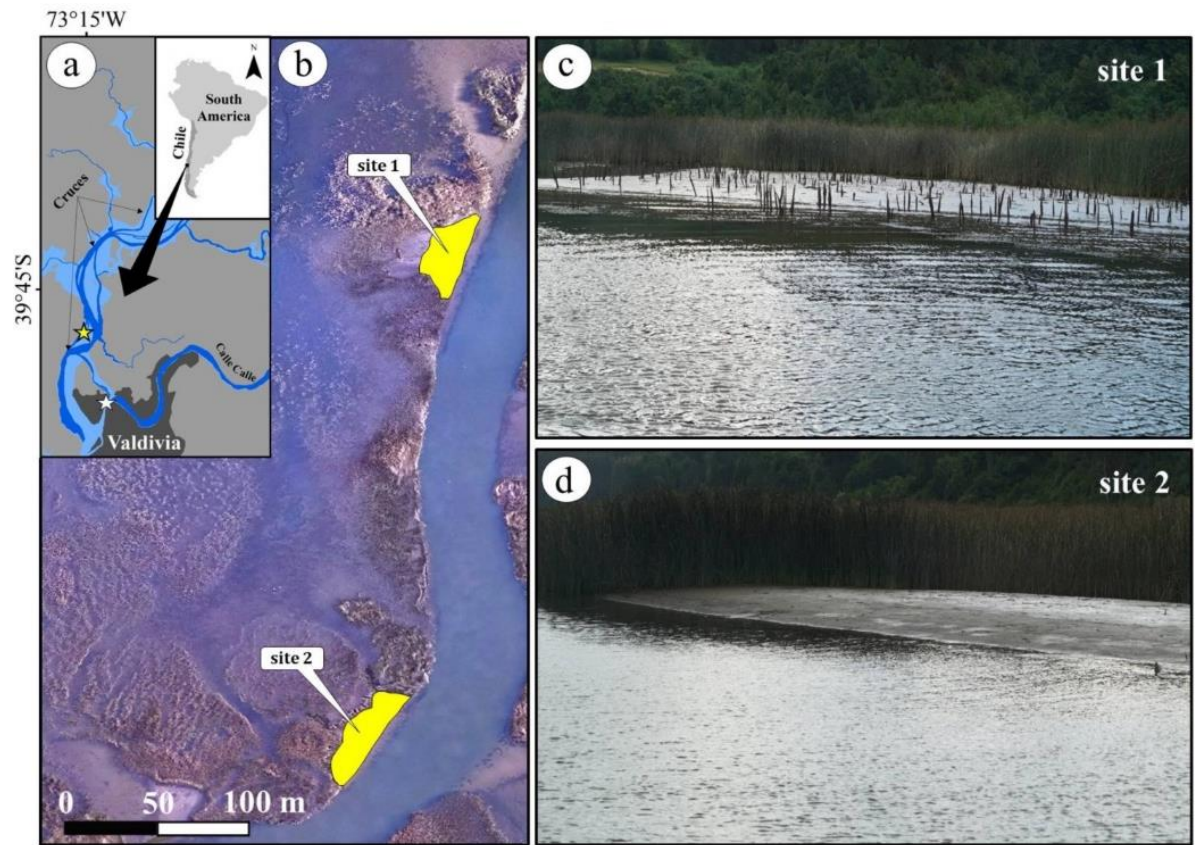

Figure 1. a) Location of Cruces River wetland in south-central Chile; the yellow star indicates the study area's location, which corresponds to the wetland's southern sector, b) zenithal aerial photograph of the area showing the locations of study sites 1 and 2, c-d) general views of tidal flats of sites 1 and 2, respectively. Note the presence of vestigial tree trunks in site 1. The white star indicates the approximate location of the tide gauge (data presented in Figure 2).

estuary characterized by semidiurnal tidal cycles (i.e. two daily $\sim 12 \mathrm{~h}$ tidal cycles) and micro-tidal ranges ( $\sim 0.7 \mathrm{~m}$, UACh 2015). The measurements were carried out during flooding (Figs. 3-4). The tidal flats are located nearly $300 \mathrm{~m}$ apart (Fig. 1b); vestigial tree trunks are present in one of them (site 1) and absent in the other (site 2) (Figs. 1c-d, respectively). The surface areas are $905 \mathrm{~m}^{2}$ (site 1) and $675 \mathrm{~m}^{2}$ (site 2). Because of the lack of instrumental equipment, the two areas were studied individually during April 17-18, 2016 (period 1) and April 25-26, 2016 (period 2), i.e. before and after the sudden rainfall event, respectively.

The depth of inundation was recorded with topographic level rods placed in the center of each tidal flat. The record was visually obtained and documented every $20 \mathrm{~min}$ for each flood duration, which we considered to be equivalent to the water column's residence time at each site. The velocities of floodbottom currents were measured with a Valeport-001 flowmeter with lower stall speed, which was deployed at $5 \mathrm{~cm}$ above the tidal flat surface and recorded data at 20 min intervals (set to compute averages from $30 \mathrm{~s}$ readings). Simultaneously, water samples (1 L) were collected every $30 \mathrm{~min}$ to analyze TSS concentration ( $\mathrm{mg} \mathrm{L}^{-1}$ ). A hydraulic pump was placed at $5 \mathrm{~cm}$ above the tidal flat surface on a smooth acrylic platform $(10 \times 10 \mathrm{~cm})$ to avoid water suction from the bottom.
The water samples were analyzed for TSS, according to Strickland \& Parsons (1972). The tidal variability estimated from a reference station located nearby (Fig. 1a) was similar for the two study periods (Fig. 2). The estimations resulting from this software are similar to those collected within the same wetland, but from fixed stations by using a Valeport tide Gauges model TidaMaster (www.valeport.co.uk) in previous studies (UACh 2015).

The second period of measurements had the longest flooding (Fig. 3), especially at site 2, which reached a maximum depth of inundations of 57 and $37 \mathrm{~cm}$ for sites 1 and 2, respectively (Fig. 3). The maximum tidal current velocities at site 1 were somewhat similar over the two periods (24 and $19 \mathrm{~cm} \mathrm{~s}^{-1}$ for period 1 and 2, respectively), whereas at site 2 increased from a maximum of $35 \mathrm{~cm} \mathrm{~s}^{-1}$ during period 1 to a maximum of $51 \mathrm{~cm} \mathrm{~s}^{-1}$ during period 2 (Fig. 3). The highest TSS concentrations were reached after the rainfall event on both sites (32 and $41 \mathrm{mg} \mathrm{L}^{-1}$ at sites 1 and 2, respectively; Fig. 4). At site 2, that maximum coincided with the highest tidal current velocities registered during the flooding event, which lasted over a more extended period than site 1 (Fig. 4).

The depth of inundation, length of flooding, velocities of tidal current, and TSS concentrations are all variables considered relevant for the deposition and 


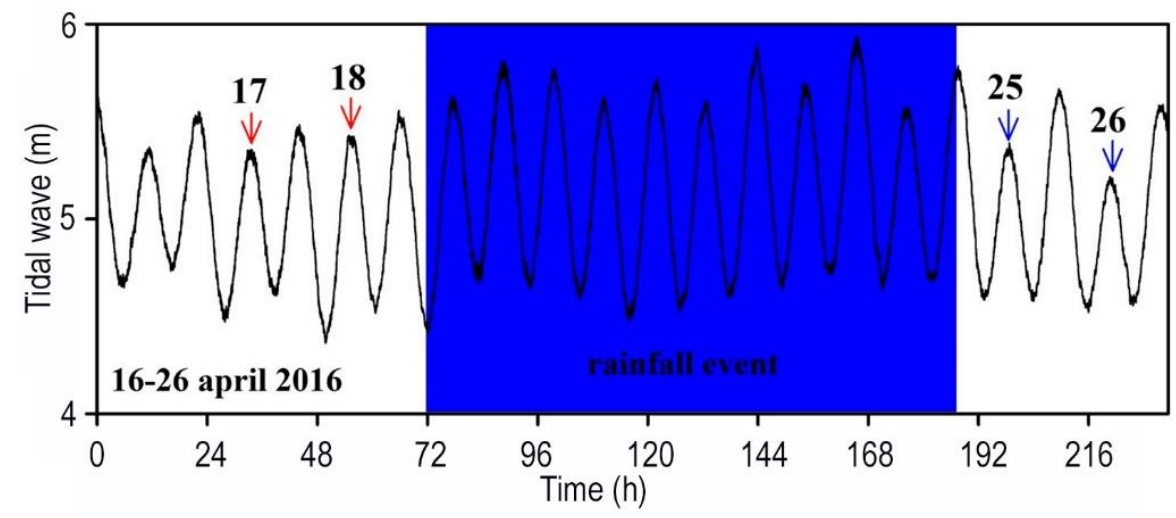

Figure 2. Tidal variability estimated with the software WXTide32 (www.wxtide32.com) for a reference station located in the city of Valdivia, nearly $1 \mathrm{~km}$ downstream sites 1 and 2 . Before the rainfall event, measurements were carried out during April 17-18 (sites 1 and 2, respectively), and after the event during April 25-26 (sites 1 and 2, respectively).
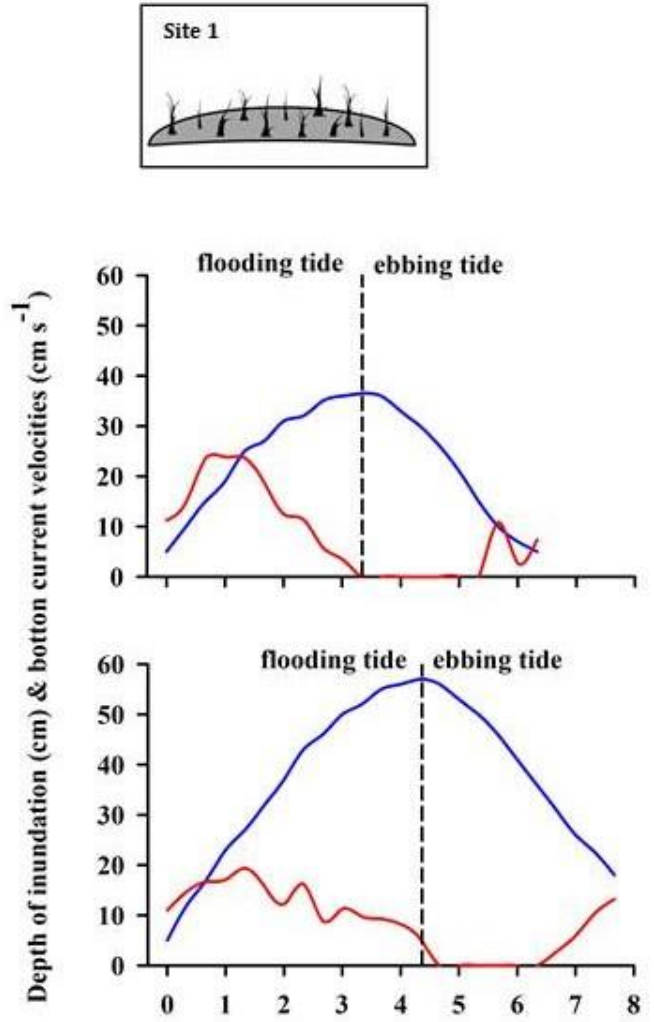

Time (h)
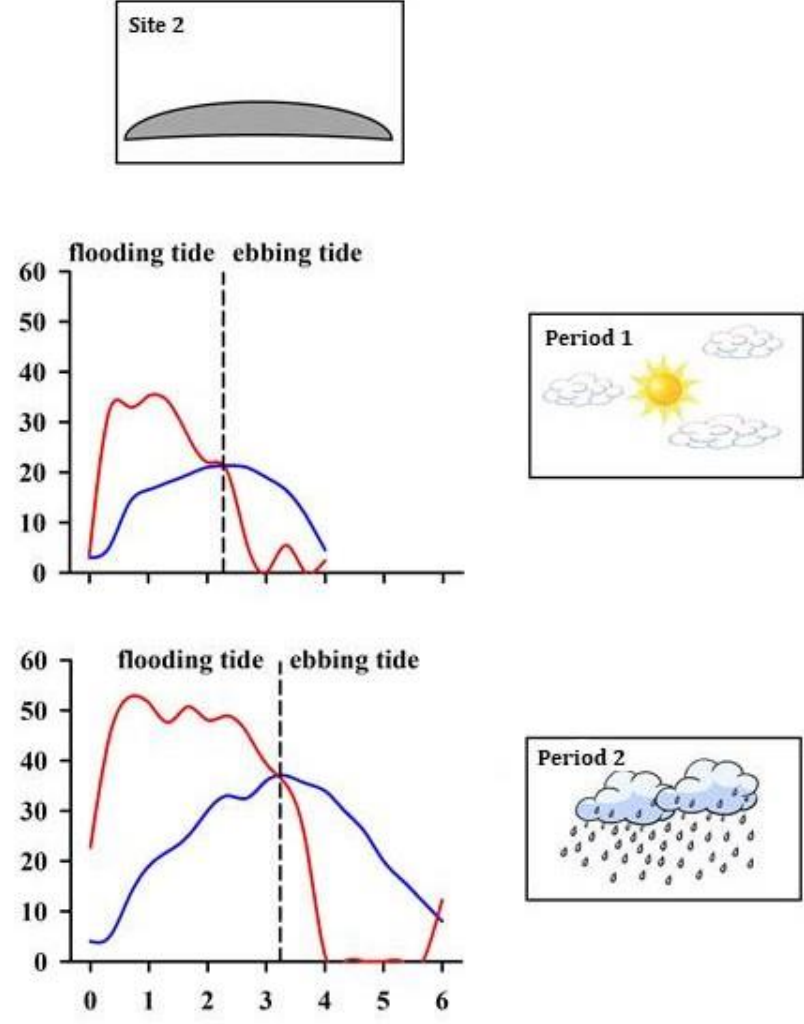

$$
\text { - Depth of inundation }(\mathrm{cm}) \quad \text { - Bottom current velocities }\left(\mathrm{cm} \mathrm{s}^{-1}\right)
$$

Figure 3. Depth of inundation $(\mathrm{cm})$ (continuous blue line) measured with a topographic rod (reference level) and bottom current velocities $\left(\mathrm{cm} \mathrm{s}^{-1}\right)$ (continuous red line) at site 1 (with tree trunks) and 2 (without tree trunks) before and after the $96 \mathrm{~mm}$ rainfall event (periods 1 and 2, respectively).

accumulation of particles on tidal flats (e.g. Van Rijn 1993, Pieterse et al. 2016). The $96 \mathrm{~mm}$ of rainfall accumulated during April 2016 increased depth of inundation by 21 and $16 \mathrm{~cm}$ at sites 1 and 2, respectively (from 36 to $57 \mathrm{~cm}$ at site 1 and from 21 to
$37 \mathrm{~cm}$ at the second site; Fig. 3). A rather general increase in the length of flood at both sites was also observed, accompanied by higher values for maximum concentrations of TSS, particularly evident on site 2 . The last results may be explained due to the absence of 

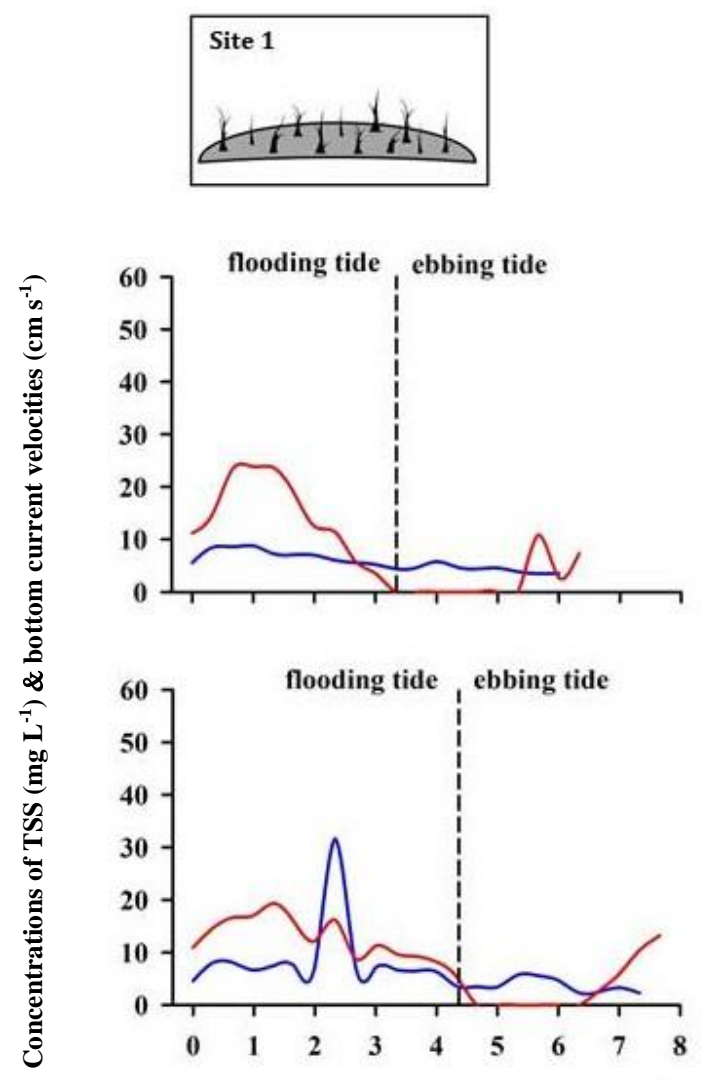

Time (h)
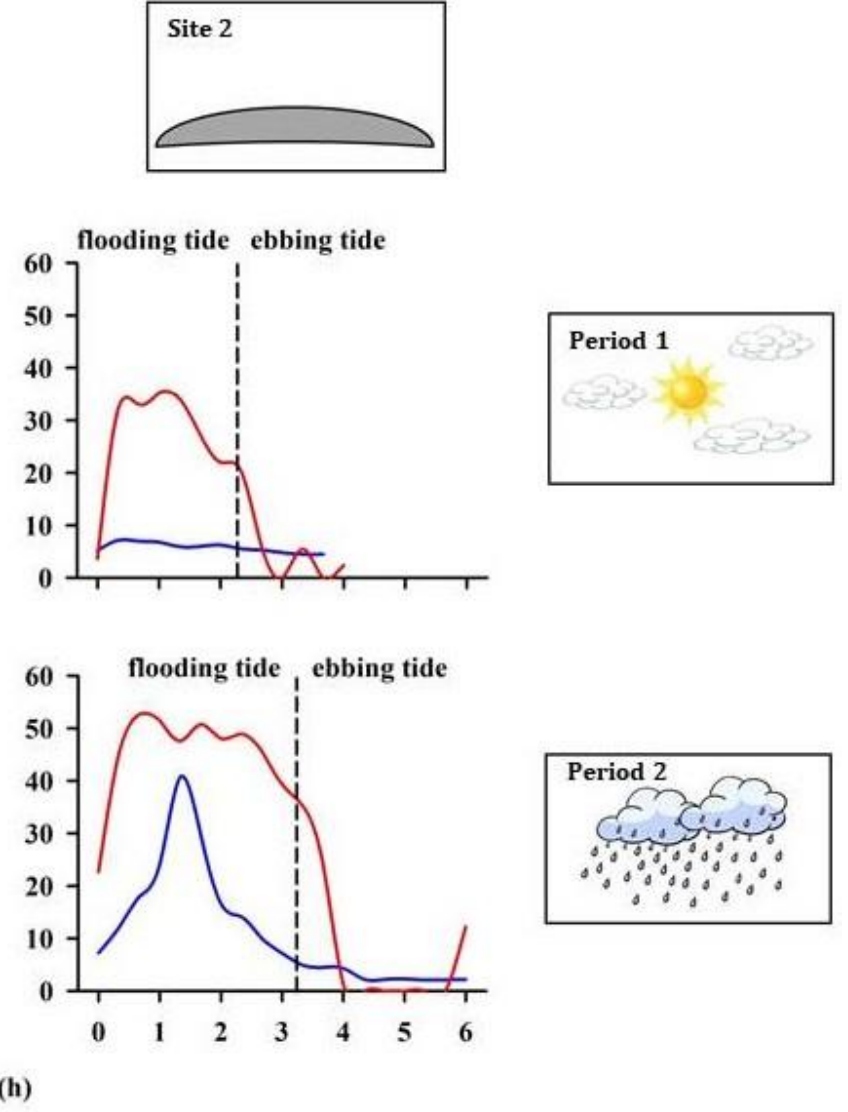

— TSS $\left(\mathrm{mg} \mathrm{L}^{-1}\right) \quad$ Bottom current velocities $\left(\mathrm{cm} \mathrm{s}^{-1}\right)$

Figure 4. Concentrations of total suspended solids (TSS) in the water $\left(\mathrm{mg} \mathrm{L}^{-1}\right)$ (continuous blue line) and bottom current velocities $\left(\mathrm{cm} \mathrm{s}^{-1}\right)$ (continuous red line), at site 1 (with tree trunks) and 2 (without tree trunks), before and after the $96 \mathrm{~mm}$ rainfall event (periods 1 and 2, respectively).

emerging structures at site 2; that would result in higher current velocities than at site 1 , where vestigial tree trunks probably slow down current velocities and thus, promoting lower resuspension of sediments and concentrations of TSS (e.g. Friedrichs et al. 2000, Perillo 2003, Bouma et al. 2007, Ma et al. 2014).

Globally, most tidal flats are bound to meso- and macro-tidal conditions ( $~ 5.7$ million $\mathrm{km}^{2}$; Bokuniewicz 1995, Perillo 1995). In micro-tidal settings, such as the estuarine Cruces River wetland and other coastal wetlands of south-central Chile, rainfall events are associated with an unusually prolonged increase of surface flooding due to a combination of the increased runoff volume of surface channels, the level of underground waters (cf. Chyan-Deng et al. 2007, Pieterse et al. 2016), and the direct accumulation of water above the water table of these habitats. Although the flooding (inundation) events triggered by the rainfall do not modify the local tidal variability in the study area, they impede the subaerial exposure of tidal flats during ebb tide (cf. Anderson et al. 1981, Anderson 1983, UACh 2015, Manzano 2019, Manzano et al. 2020). With some exceptions (Pino et al. 1999), those processes have not been studied in detail in Chilean estuarine flats. It is not trivial because a decrease in rainfall in the context of global climate change could trigger important changes in the maintenance of tidal flats in coastal estuarine wetlands of south-central Chile (Galbraith et al. 2002, Miththapala 2013, Manzano et al. 2020).

\section{ACKNOWLEDGMENTS}

This study was funded by the contract Arauco y Constitución S.A. \& UACh "Environmental Monitoring Program of the Río Cruces wetland and its tributary systems 2015-2020". M. Manzano thanks CONICYT (National Commission for Scientific and Technological Research) for supporting grant 21130203 (Program National Doctoral Scholarships and Operational Costs). 


\section{REFERENCES}

Anderson, F.E. 1983. The northern muddy intertidal: seasonal factors controlling erosion and deposition - a review. Canadian Journal of Fisheries and Aquatic Sciences, 40: 143-159.

Anderson, F.E., Black, L., Watling, L.E., Mook, W. \& Mayer, L.M. 1981. A temporal and spatial study of mudflat erosion and deposition. Journal of Sedimentary Research, 51: 729-736.

Bokuniewicz, H. 1995. Sedimentary systems of coastal-plain estuaries. In: Perillo, G.M.E. (Ed.). Geomorphology and Sedimentology of Estuaries, 53: 49-65.

Bouma, T.J., Van Duren, L.A., Temmerman, S., Claverie, T., Blanco-Garcia, A., Ysebaert, T. \& Herman, P.M.J. 2007. Spatial flow and sedimentation patterns within patches of epibenthic structures: combining field, flume and modelling experiments. Continental Shelf Research, 27: 1020-1045.

Feuker, P. 2006. Alzamiento y subsidencia cosísmica en el área de Valdivia durante el terremoto del 22 de mayo de 1960. XI Congreso Geológico Chileno, Actas Vol. 2. Geodinámica Andina, Antofagasta, Chile.

Friedrichs, M., Graf, G. \& Springer, B. 2000. Skimming flow induced over a simulated polychaete tube lawn at low population densities. Marine Ecology Progress Series, 192: 219-228.

Galbraith, H., Jones, R., Park, R., Clough, J., HerrodJulius, S., Harrington, B. \& Page, G. 2002. Global climate change and sea level rise: potential losses of intertidal habitat for shorebirds. Waterbirds, 25: 173183.

Hackney, C.T. \& Avery, G.B. 2015. Tidal wetland community response to varying levels of flooding by saline water. Wetlands, 35: 227-236.

Chyan-Deng, J., Tsung-Hsien, C.B. \& Wei-Cheng, L. 2007. Effect of rainfall intensity and distribution on groundwater level fluctuations. Journal of Hydrology, 332: 348-360.

Lindenmayer, D.B., Knight, E., McBurney, L., Michael, D. \& Banks, S.C. 2010. Small mammals and retention islands: an experimental study of animal response to alternative logging practices. Forest Ecology and Management, 260: 2070-2078.

Ma, G., Han, Y., Niroomandi, A., Lou, S. \& Liu, S. 2014. Numerical study of sediment transport on a tidal flat with a patch of vegetation. Ocean Dynamics, 65: 203222.

Received: 27 February 2020; Accepted: 27 November 2020
Manzano, M.A. 2019. Respuestas físico-biológicas a la heterogeneidad ambiental de planicies sedimentarias intermareales en el humedal estuarial del Río Cruces, sur de Chile. Tesis Doctoral, Universidad Austral de Chile, Valdivia.

Manzano, M., Jaramillo, E. \& Pino, M. 2020. Tidal flats of recent origin: distribution and sedimentological characterization in the estuarine Cruces River wetland, Chile. Latin American Journal of Aquatic Research, 48: 662-673. doi: 10.3856/vol48-issue4-fulltext-2381

Miththapala, S. 2013. Tidal flats. Coastal Ecosystems Series, 5: $48 \mathrm{pp}$.

Perillo, G.M.E. 1995. Definition and geomorphologic classifications of estuaries. In: Perillo, G.M.E. (Ed.). Geomorphology and Sedimentology of Estuaries, 53: 17-47.

Perillo, G.M.E. 2003. Dinámica del transporte de sedimentos. Asociación Argentina de Sedimentología, La Plata.

Pino, M., Busquets, T. \& Brummer, R. 1999. Temporal and spatial variability in the sediments of a tidal flat, Queule River estuary, south-central Chile. Revista Geológica de Chile, 26: 187-204.

Pieterse, A., Puleo, J. \& McKenna, T.E. 2016. Hydrodynamics and sediment suspension in shallow tidal channels intersecting a tidal flat. Continental Shelf Research, 119: 40-55.

Plafker, G. \& Savage, J.C. 1970. Mechanism of the Chilean earthquakes of May 21 and 22, 1960. Geological Society of America Bulletin, 81: 10011030.

Reinhardt, E.G., Nairn, R.B. \& López, G. 2010. Recovery estimates for the Río Cruces after the May 1960 Chilean earthquake. Marine Geology, 269: 18-33.

Strickland, J.D.H. \& Parsons, T.R. 1972. A practical handbook of seawater analysis. Fisheries Research Board of Canada, Bulletin 167, Ottawa.

Universidad Austral de Chile (UACh). 2015. Programa de diagnóstico ambiental del humedal del Río Cruces y sus ríos tributarios: 2014-2015. Informe Final. Convenio Arauco y Constitución S.A. \& Universidad Austral de Chile, Valdivia.

Van Rijn, L. 1993. Principles of sediment transport in rivers, estuaries and coastal seas. Aqua Publications, Overijssel. 